Zagazig Veterinary Journal

Volume 44, Number 1, p. 1-8, June, 2016

CFaculty of Veterinary Medicine, Zagazig University, 44511, Egypt

DOI: 10.21608/zviz.2016.7826.

\title{
Molecular Characterization and Antibiotic Susceptibility of Corynebacterium pseudotuberculosis Isolated from Sheep and Goats Suffering from Caseous Lymphadenitis
}

\author{
Abdelazeem M. Algammal \\ Department of Bacteriology, Mycology and Immunology, Faculty of Veterinary Medicine, Suez \\ Canal University, Ismailia, Egypt.
}

Article History: Received: 16/2/2016 Received in revised form: 17/3/2016 Accepted: 30/3/2016

\begin{abstract}
Caseous lymphadenitis is a highly prevalent worldwide disease of sheep and goats caused by $C$. pseudotuberculosis, resulting in significant economic losses. In order to investigate the prevalence as well as the molecular characterization of $C$. pseudotuberculosis and monitoring the antibiotic susceptibility of the isolated strains, a total of 126 pus samples were collected aseptically from 80 sheep and 46 goats suffering from abscessation. The collected samples were subjected to bacteriological examination where the prevalence of $C$. pseudotuberculosis was $43.8 \%$ and $36.9 \%$ in diseased sheep and goats, respectively. The antibiotic sensitivity test was carried out using disc diffusion method, most of the isolates were resistant to penicillin (96.2\%) and erythromycine (92.3\%), highly sensitive to ciprofloxacin $(96.2 \%)$, amikacin $(90.4 \%)$ and neomycin $(88.5 \%)$. Polymerase chain reaction was applied on 30 C. pseudotuberculosis isolates for the amplification and detection of both $16 \mathrm{~S}$ rRNA and the RNA polymerase $\beta$-subunit gene (rpoB) genes to confirm the diagnosis of the isolates. The results revealed that all the tested isolates were positive for both genes. In conclusion, the incorporation of both phenotypic and genotypic characterization of C.pseudotuberculosis is more valuable and accurate for identification of isolates. Moreover, PCR is a fast and specific diagnostic tool used for the genetic analysis of $C$. pseudotuberculosis.
\end{abstract}

Keywords: Caseous lymphadenitis, C. pseudotuberculosis, 16S rRNA, rpoB

\section{Introduction}

Caseous lymphadenitis is a chronic debilitating disease affecting sheep and goats and is characterized by fibrous encapsulated suppurative abscesses in the peripheral lymph nodes and visceral organs that incorporate yellowish green granular pus [1,2]. The disease results in severe economic losses to sheep and goat producers worldwide, in particular due to the reduction of milk yield, wool and meat production, decreasing the fertility of the affected animals and condemnation of portions of affected carcasses at slaughter $[3,4]$.

Genus Corynebacterium is one of the members of the Actinomycetes group. Other Genera are also included in this group such as Nocardia and Mycobacterium. Although these genera belonged to the same group, they greatly differ in many characters including cell wall composition, the percentage of peptidoglycan and mycolic acid and the guanine and cytosine ratio in their genome.

The Actinomycetes group includes several species which have both medical and veterinary importance, such as Mycobacterium tuberculosis and $M$. bovis; the causative agents of human and bovine tuberculosis; and $C$. pseudotuberculosis which is the main causative agent of caseous lymphadenitis [1].

C. pseudotuberculosis is Gram-positive, pleomorphic, non-capsulated, non-motile, non sporulating, facultative anaerobic and intracellular microorganism with worldwide distribution $[5,6]$.

*Corresponding author e-mail: (immunologist222@yahoo.com), Department of Bacteriology, Mycology and Immunology, Faculty of Veterinary Medicine, Suez Canal University, Ismailia, Egypt. 
The microorganism is classified into two biovars, the biovar Ovis (nitrate reduction negative), which mainly affects sheep and goats causing caseous lymphadenitis and the biovar Equi (nitrate reduction positive), which mainly affects horses and cattle causing ulcerative lymphangitis. The existence of these two biovars has been confirmed by biomolecular techniques $[7,8]$.

Caseous lymphadenitis is mainly transmitted through abscess rupture which results in discharge of large numbers of $C$. pseudotuberculosis which contaminate the sheep fleece, and in turn the surrounding environment became contaminated. The transmission of infection to other animals could be either by direct contact with the diseased animal or indirect contact with the contaminated environment [5].

Caseous lymphadenitis diagnosis mainly depends upon the disease clinical characteristics and the isolation and identification of the causative agent from pus discharge. Molecular typing of $C$. pseudotuberculosis is necessary to confirm the diagnosis of caseous lymphadenitis. Polymerase chain reaction (PCR) is a reliable, accurate and rapid technique if compared with the conventional techniques used for isolation and identification of bacterial pathogens. PCR detection and amplification of $16 \mathrm{~S}$ rRNA and the RNA polymerase $\beta$-subunit gene (rpoB) genes facilitates the differential diagnosis of $C$. pseudotuberculosis from other bacterial pathogens that may be present in pus samples [1].

This study was planned to investigate the prevalence of $C$. pseudotuberculosis affecting sheep and goats, monitoring the antimicrobial susceptibility of the isolated strains and PCR based detection of $16 \mathrm{~S}$ rRNA and rpoB genes in order to confirm the diagnosis of the isolated C. pseudotuberculosis strains.

\section{Material and Methods}

\section{Sampling}

A total of 126 pus samples were collected aseptically from 80 sheep and 46 goats suffering from abscessation (clinically examined for the presence of abscess in the superficial lymph nodes including prescapular, pre-femoral, sub-mandibular and parotid lymph nodes) at different farms in Menoufia Governorate, Egypt. Pus samples were aseptically collected from opened abscesses by sterile swabs. The collected samples were kept on ice and brought to the lab as soon as possible.

\section{Isolation and identification of $C$. pseudotuberculosis}

Pus samples were directly inoculated onto blood agar base (Oxoid) supplemented with $5 \%$ defibrinated sheep blood. Plates were incubated at $37^{\circ} \mathrm{C}$ for $48-72 \mathrm{~h}$, suspected pure colonies (yellowish white, opaque, hemolytic and convex colonies) were identified morphologically using Gram's stain as well as biochemically (catalase and urease activities, nitrate reduction and carbohydrates fermentation including glucose, lactose, maltose and galactose) using methods described by Quinn et al. [9].

\section{Antimicrobial susceptibility testing by disc diffusion method}

The susceptibility to eight antibiotics (penicillin, amikacin, neomycin, erythromycine, ciprofloxacin, sreptomycin, novobiocin and methicillin) was tested according to the National Committee for Clinical Laboratory Standards (NCCLS, 2013) using disc diffusion technique [10]. The susceptibility of the strains was determined according to the size of the inhibition zone.

\section{PCR detection of 16SrRNA gene and rpoB genes of C. pseudotuberculosis}

Randomly chosen 30 isolates were subjected to PCR for the detection of $16 \mathrm{~S}$ rRNA and rpoB genes.

DNA extraction

Extraction of DNA from C.pseudotuberculosis strains by boiling method was carried out according to Faez et al. [11]. One $\mathrm{ml}$ of the bacterial broth culture was centrifuged at $5000 \mathrm{rpm}$ for $5 \mathrm{~min}$, the supernatant was discarded and the pellet was 
re-suspended in $1 \mathrm{ml}$ distilled water. Centrifugation at $5000 \mathrm{rpm}$ for $5 \mathrm{~min}$ and washing in another $1 \mathrm{ml}$ distilled water was repeated for three times. The pellet was resuspended in $200 \mu \mathrm{l}$ distilled water for boiling for $10 \mathrm{~min}$. The suspension was then placed in ice for $5 \mathrm{~min}$, and centrifuged at $10000 \mathrm{rpm}$ for 5 min. The supernatant (containing the bacterial DNA) was then transferred to a fresh tube.

\section{Amplification of the target genes}

The amplification of $16 \mathrm{~S}$ rRNA and rpoB genes was carried out according to Çetinkaya et al. [12] and Pacheco et al. [13], respectively, using specific primer sets Synthesized by metabion company, Germany were used (Table 1). The reaction was performed in a total volume of $50 \mu \mathrm{l}$ containing PCR buffer [(50 mM Kcl, $10 \mathrm{mM}$ tris - Hcl, $1 \mathrm{mM} \mathrm{Mgcl}_{2}$ ), dNTPS (Deoxy nucleotide Triphosphate) $200 \mathrm{uM}$, each (dATP, dGTP, dCTP and dTTP) (Advanced Bio enzymes ltd. UK), Two primer pairs each at $50 \mathrm{pmol} / \mathrm{reaction}$, and $1.25 \mathrm{U}$ of Taq DNA polymerase (Advanced Bio enzymes ltd. UK). Thermal cycling in a programmable thermal cycler (Coy corporation, Grass Lake, Michgan, USA) was done. A positive control was kindly provided by the Department of Bacteriology, Mycology and Immunology, Faculty of Veterinary Medicine, Suez Canal University, Ismailia. Egypt. A negative control PCR reaction with no template was also included in this assay.

The reaction conditions for the amplification of $16 \mathrm{~S}$ rRNA were initial denaturation $\left(94^{\circ} \mathrm{C}\right.$ for $\left.5 \mathrm{~min}\right), 30$ cycles (denaturation at $94^{\circ} \mathrm{C}$ for $1 \mathrm{~min}$; annealing at $56{ }^{\circ} \mathrm{C}$ for $1 \mathrm{~min}$; extension at $72^{\circ} \mathrm{C}$ for $1 \mathrm{~min}$ ) and final extension at $72^{\circ} \mathrm{C}$ for 5 minutes [12]. For the amplification of rpoB gene, the reaction conditions were initial denaturation $\left(95^{\circ} \mathrm{C}\right.$ for $\left.3 \mathrm{~min}\right), 35$ cycles (denaturation at $95^{\circ} \mathrm{C}$ for $1 \mathrm{~min}$, annealing at $55^{\circ} \mathrm{C}$ for $40 \mathrm{~s}$; extension at $68^{\circ} \mathrm{C}$ for $1 \mathrm{~min}$ ) and final extension at $68^{\circ} \mathrm{C}$ for $5 \mathrm{~min}$ [13].

Table 1: Oligonucleotide primers used for PCR assay for $C$. pseudotuberculosis

\begin{tabular}{|c|c|c|c|c|}
\hline Primer & $\begin{array}{l}\text { Primer Sequence } \\
5^{\prime}-3^{\prime}\end{array}$ & $\begin{array}{l}\text { Annealing } \\
\text { temperature }\end{array}$ & $\begin{array}{c}\text { PCR } \\
\text { product (bp) }\end{array}$ & Reference \\
\hline $\begin{array}{l}\text { 16S rRNA- F } \\
16 S \text { rRNA- R }\end{array}$ & $\begin{array}{l}\text { ACCGCACTTTAGTGTGTGTG } \\
\text { TCTCTACGCCGATCTTGTAT }\end{array}$ & $56^{\circ} \mathrm{c}$ & 815 & [12] \\
\hline $\begin{array}{l}\text { rpoB-F } \\
\text { rpoB-R }\end{array}$ & $\begin{array}{l}\text { CGTATGAACATCGGCCAGGT } \\
\text { TCCATTTCGCCGAAGCGCTG }\end{array}$ & $68^{\circ} \mathrm{c}$ & 446 & [13] \\
\hline
\end{tabular}

\section{Screening of the PCR products}

Ten $\mu 1$ of the amplified PCR product was analyzed by electrophoresis in $2 \%$ agarose gel stained with $0.5 \mu \mathrm{g}$ of ethidium bromide/ml (Sigma). Electrophoresis was carried out in $1 \mathrm{X}$ TAE buffer at 80 volt for 1 hour. Gels were visualized under UV transilluminator (UVP, UK) and photographed.

\section{Results}

\section{Prevalence of $C$. pseudotuberculosis in diseased sheep and goats}

C. pseudotuberculosis was isolated from 35 (43.8\%) and $17(36.9 \%)$ diseased sheep and goats, respectively, with an overall isolation rate of $41.3 \%$ (Table 2). Seventy four samples
(45 from sheep and 29 from goats) were negative for $C$. pseudotuberculosis, while, they were positive for other bacterial pathogens.

\section{Antibiogram analysis of the isolated $C$. pseudotuberculosis strains}

As shown in Table (3), the antibiotic sensitivity test revealed that, most of the examined $C$. pseudotuberculosis isolates were highly resistant to penicillin (96.2\%) and erythromycine $(92.3 \%)$, while they were highly sensitive to ciprofloxacin (96.2\%), amikacin (90.4\%), neomycin $(88,5 \%)$ and streptomycin $(80.8 \%)$. Moderate sensitivity to novobiocin $(86.6 \%)$ and methicillin $(76.9 \%)$ was also observed. 
Table 2: Prevalence of $C$. pseudotuberculosis isolated from diseased sheep and goats

\begin{tabular}{lcccc}
\hline $\begin{array}{l}\text { Animal } \\
\text { spp. }\end{array}$ & $\begin{array}{l}\text { No. of pus } \\
\text { samples }\end{array}$ & $\begin{array}{l}\text { No. of } \boldsymbol{C} \text {. } \\
\text { pseudotuberculosis }\end{array}$ & $\begin{array}{l}\text { \% of } \boldsymbol{C} \text {. } \\
\text { pseudotuberculosis }\end{array}$ & $\begin{array}{l}\text { No of samples positive for } \\
\text { other bacterial pathogens }\end{array}$ \\
\hline Sheep & 80 & 35 & 43.75 & 45 \\
Goats & 46 & 17 & 36.95 & 29 \\
Total & 126 & 52 & 41.26 & 74 \\
\hline
\end{tabular}

Table 3: Antibiogram of the isolated $C$. pseudotuberculosis

\begin{tabular}{|c|c|c|c|c|c|c|}
\hline \multirow[t]{2}{*}{ Antimicrobial agents } & \multicolumn{2}{|c|}{ Resistant } & \multicolumn{2}{|c|}{ Intermediate } & \multicolumn{2}{|c|}{ Sensitive } \\
\hline & No & $\%$ & No & $\%$ & No & $\%$ \\
\hline Penicillin & 50 & 96.2 & 2 & 3.9 & - & - \\
\hline Ciprofloxacin & - & - & 2 & 3.9 & 50 & 96.2 \\
\hline Neomycin & - & - & 6 & 11.6 & 46 & 88.5 \\
\hline Amikacin & - & - & 5 & 9.6 & 47 & 90.4 \\
\hline Novobiocin & 7 & 13.5 & 45 & 86.5 & - & - \\
\hline Erythromycine & 48 & 92.3 & 4 & 7.7 & - & - \\
\hline Sreptomycin & - & - & 10 & 19.2 & 42 & 80.8 \\
\hline Methicillin & 10 & 19.3 & 40 & 76.9 & 2 & 3.8 \\
\hline
\end{tabular}

\section{Molecular characterization of $C$. pseudotuberculosis}

In the present work, thirty $C$. pseudotuberculosis isolates were subjected to PCR amplification of $16 \mathrm{~S}$ rRNA and rpoB genes in order to confirm the bacteriological identification of the isolates. All the selected C. pseudotuberculosis isolates were positive for both 16S rRNA and rpoB genes (Figures 1 and 2).

\section{Discussion}

Caseous lymphadenitis is a chronic disease of veterinary importance affecting sheep and goats resulting in excessive economic losses of animal industry worldwide $[3,4]$. In the present study, the prevalence of $C$. pseudotuberculosis in the affected sheep and goats was $43.8 \%$ and $36.9 \%$, respectively (Table 2 ).

C. pseudotuberculosis was reported from cases of abscessation in sheep and goats with the isolation rates of $26.3 \%$ and $45.5 \%$, respectively, in Egypt [14]. Higher prevalence in sheep and goats (70\%) was recorded in Patagonia [15]. In addition, in Turkey, 96 suspicious Corynebacterium isolates from sheep and goat abscesses were confirmed by $16 \mathrm{~S}$ rRNA as C. pseudotuberculosis [12].

The usage of the barbed wire fences for guarding the sheep and goats farms is one of the maximum vital bad management practices that cause wounds with subsequent infection [16]. The disease is mainly transmitted through abscesses rupture and other animals could be subjected to $C$. pseudotuberculosis infection, either by direct contact with the diseased animal or indirect infection through the contaminated environment [5]. Caseous lymphadenitis has been reported in countries formerly free from the disease, which mainly attributed to importation of diseased cases [17]. C. pseudotuberculosis isolates showed resistance to penicillin (96.2\%) and erythromycine $(92.3 \%)$ and they were highly sensitive to ciprofloxacin (96.2\%), amikacin $(90.4 \%)$ neomycin $(88.5 \%)$ and streptomycin $(80.8 \%)$. Moderate sensitivity to novobiocin $(86.6 \%)$ and methicillin $(76.9 \%)$ was also observed (Table 3 ).

These results were in accordance with those obtained by Hatem et al. [14] in Egypt and Hassan et al. [18] in Saudi Arabia. In contrary, Abdel Wahab and Shigidi [19] reported that C. pseudotuberculosis isolates were highly sensitive to erythromycin and ampicillin. Based upon the results of several studies on different Corynebacterium spp. showing resistance to penicillins, it could be concluded that both resistance mechanisms occur in Corynebacterium spp., including synthesis of penicillinase enzymes and alteration of 
penicillin-binding proteins [20]. Resistance to macrolides, (erythromycin), mainly occurred due to three major mechanisms: change of the ribosome binding site (23S rRNA) (methylation) or modification in the mode of active efflux of the antibiotic from the cell or antibiotic inhibition by enzymes [21,22].
Methylation prevents binding of the antibiotic molecules in the peptidyltransferase center within the large ribosome subunit. Corynebacterium spp. carry genes of class erm (erythromycin ribosome methylation), encoding the methylase enzyme, which causes methylation of $23 \mathrm{~S}$ rRNA.

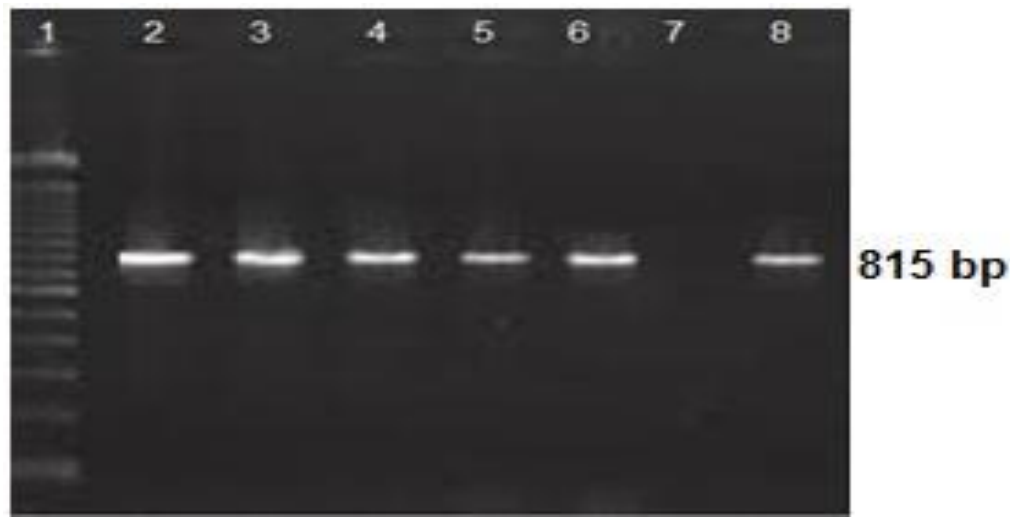

Figure 1: Electrophoretic pattern of 16S rRNA gene in 2\% agarose gel showing the amplified product at 815 bp [lane (1): 100 bp DNA ladder, lanes (2-6): positive samples, lane (7): control negative, lane (8): control positive $C$. pseudotuberculosis strain].

The traditional bacteriological methods are not usually completely accurate, as a result, the development of a fast and specific diagnostic tool is vital for early diagnosis and control of caseous lymphadenitis [12].

In the current study, PCR was used for the detection and amplification of $16 \mathrm{~S}$ rRNA gene in order to confirm the diagnosis of the isolated strains. The $16 \mathrm{~S}$ rRNA gene, the gene of choice for most microbial taxonomy studies, therefore, this gene is useful for estimating the prevalence of $C$. pseudotuberculosis in the animals studied [12]. All the selected C. pseudotuberculosis isolates were positive for $16 \mathrm{~S}$ rRNA gene with the specific 815 bp amplicon size (Figure 1). In addition, amplification of $r p o B$ gene in the obtained isolates was also carried out (Figure 2).

All the examined isolates were positive with the specific amplicon size (446 bp). these results agreed with those reported by other studies [13,23]. PCR detection of both $16 \mathrm{~S}$ rDNA and rpoB genes help in the differential diagnosis of $C$. pseudotuberculosis from other pyogenic pathogens that might present in pus discharge [13]. 


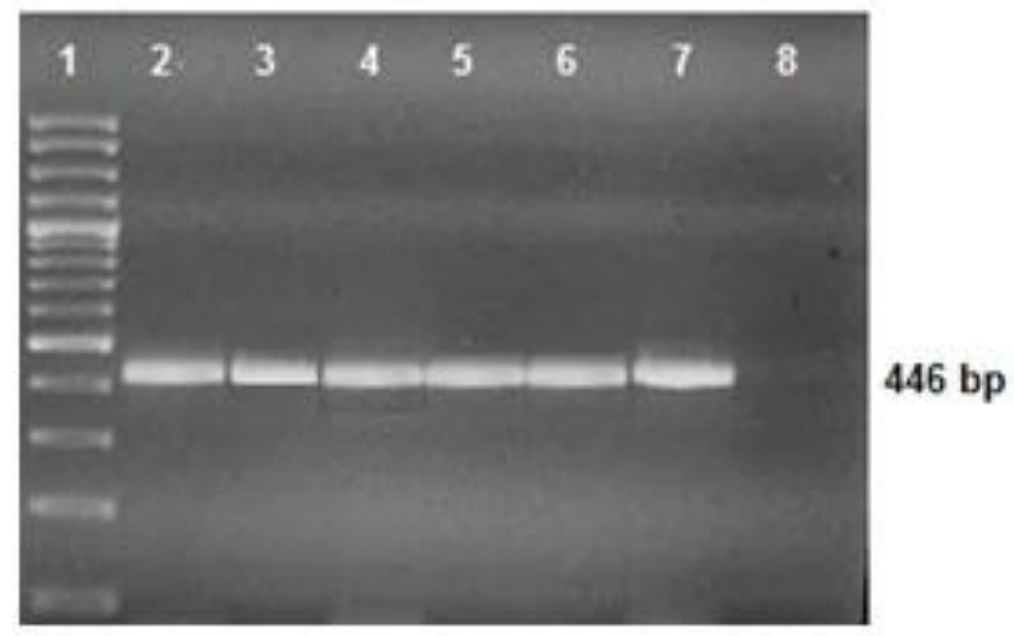

Figure 2: Electrophoretic pattern of rpoB gene in $2 \%$ agarose gel showing the amplified product at 446 bp [lane 1: 100 bp DNA ladder, lane (2): control positive $C$. pseudotuberculosis strain, lanes (3-7): positive samples, lane (8): control negative].

Similarity in the sequence of $16 \mathrm{~S}$ rRNA $(99.7 \%)$ and rpoB gene $(93.6 \%)$ between $C$. pseudotuberculosis and $C$. ulcerans have been previously reported [12,13]. However, $C$. ulcerans have not been isolated in small ruminants [12]. A study by Khamis et al. [24] on the sequence analysis of $r p o \mathrm{~B}$ gene from different pyogenic bacteria reported that PCR of $r p o \mathrm{~B}$ gene is a powerful diagnostic tool that can be used to accomplish the 16S rRNA gene characterization of Corynebacterium species from other pyogenic organisms [24].

\section{Conclusion}

In conclusion, incorporation of both phenotypic and molecular characterization of C. pseudotuberculosis is more reliable and more accurate for identification of the isolates. Continuous monitoring of the antimicrobial susceptibility is necessary due to the increased microbial resistance and for selection of the antibiotic of choice. PCR is a fast and specific diagnostic tool used for the characterization of C. pseudotuberculosis.

\section{Conflict of interest}

The authors declare no conflict of interest.

\section{References}

[1] Dorella, F.A.; Pacheco, L.G.; Oliveira, S.C.; Miyoshi, A. and Azevedo, V. (2006): pseudotuberculosis: Corynebacterium biochemical properties, pathogenesis and molecular studies of virulence. Vet Res, 37 (2): 201-218.

[2] Reboucasm , M.F.; Portela, R.W.; Lima, D.D.; Loureiro, D.; Bastos, B.L.; Moura-Costa, L.F.; Vale, V.L.; Miyoshi, A.; Azevedo, V. and Meyer, R. (2011): Corynebacterium pseudotuberculosis secreted antigeninduced specific gamma-interferon production by peripheral blood leukocytes: Potential diagnostic marker for caseous lymphadenitis in sheep and goats. J Vet Diagn Invest, 23 (2): 213-220.

[3] Peel, M.M.; Palmer, G.G.; Stacpoole, A.M. and Kerr, T.G. (1997): Human lymphadenitis due to Corynebacterium pseudotuberculosis: report of ten cases from Australia and review. Clin Infect Dis, 24 (2): 185-191.

[4] Pekelder, J.J. (2000): Caseous lymphadenitis. In: Diseases of Sheep. Blackwell Science,Oxford, pp. 270-274.

[5] Baird, G.J. and Fontaine, M.C. (2007): Corynebacterium pseudotuberculosis and its role in ovine caseous lymphadenitis. $\mathbf{J}$ Comp Pathol, 137 (4): 179-210.

[6] Robles, C.A. (2007): South America: Patagonia. In: Diseases of Sheep. Blackwell Publishing Ltd., Oxford, pp. 524-534. 
[7] Sutherland, S.S.; Hart, R.A. and Buller, N.B. (1996): Genetic differences between nitrate-negative and nitrate-positive Corynebacterium pseudotuberculosis strains using restriction fragment length polymorphisms. Vet Microbiol, 49 (1-2): $1-9$.

[8] Connor, K.M.; Fontaine, M.C.; Rudge, K.; Baird, G.J. and Donachie,W. (2007): Molecular genotyping of multinational ovine and caprine Corynebacterium pseudotuberculosis isolates using pulsedfield gel electrophoresis. Vet Res, 38 (4): 613-623.

[9] Quinn, P.J.; Markey, B.K.; Leonard, F.C.; Hartigan, P.; Fanning, S. and FitzPatrick, E.S. (2011): Veterinary microbiology and microbial disease, 2nd edition. Chichester, West Sussex, UK : Wiley-Blackwell

[10] NCCLS (National Committee for Clinical and Laboratory Standards Institute) (2013): Performance standards for antimicrobial susceptibility testing; 23rd informational supplement. CLSI M100-S23. Clinical and Laboratory Standards Institute, Wayne, PA.

[11] Faez, F.J.; Lawan, A.; Abdinasir, Y.O.; Ahmad, F.B.; Abd Wahid, H.; Abdul Aziz, S.; Mohd Zamri, S. and Abdul Rahman, O. (2013): Polymerase chain reaction detection of $C$. pseudotuberculosis in the brain of mice following oral inoculation. Int $\mathrm{J}$ Animal Vet Advances, 5(1): 29-33.

[12] Çetinkaya, B.; Karahan, M.; Atil, E.; Kalin, R. ; De Baere, T. and Vaneechoutte, M. (2002): Identification of Corynebacterium pseudotuberculosis isolates from sheep and goats by PCR. Vet. Microbiol, 88 (1): 75-83.

[13] Pacheco, L.G.; Pena, R.R.; Castro, T.L.; Dorella, F.A.; Bahia, R.C.; Carminati, R.; Frota, M.N.; Oliveira, S.C.; Meyer, R.; Alves, F.S.; Miyoshi, A. and Azevedo, V. (2007): Multiplex PCR assay for identification of
Corynebacterium pseudotuberculosis from pure cultures and for rapid detection of this pathogen in clinical samples. J Med Microbiol, 56(4): 480-486

[14] Hatem, M.E.; Arab, R.H.; Ata, N.S.; Abd El-Moez, S.I.; Khairy, E.A. and Fouad, E.A. (2013) Bacterial abscessation in sheep and goat in Giza Governorate with full antibiogram screening. Global Veterinaria, 10 (4): 372-381.

[15] Robles, C. and Olaechea, F. (2001) Salud $\mathrm{y}$ enfermedades de las majadas. In: Ganaderia ovina sustentable en la Patagonia Austral. Tecnologia de manejo extensivo. Instituto Nacional de Tecnologia Agropecuaria, Argentina, 225243.

[16] Guimarães, A.S.; Carmo, F.B; Heinemann, M.B.; Portela, R.W.; Meyer, R.; Lage, A.P.; Seyffert, N.; Miyoshi, A.; Azevedo, V. and Gouveia, A.M. (2011): High sero-prevalence of caseous lymphadenitis identified in slaughter house samples as a consequence of deficiencies in sheep farm management in the state of Minas Gerais, Brazil. BMC Vet Res, 7:68. doi:10.1186/1746-6148-768.

[17] Moller, K.; Agerholm, J.S.; Ahrens, P.; Jensen, N.E. and Nielsen, T.K. (2000): Abscess disease, caseous lymphadenitis, and pulmonary adenomatosis in imported sheep. J Vet Med B Infect Dis Vet Public Health, 47 (1): 55-62.

[18] Hassan, N.A.; Al-Humiany, A.; Bahoboil, A.S. and Mansour, A.M. (2011) : Bacteriological and pathological studies on caseous lymphadenitis in sheep in Saudi Arabia. Inter $\mathbf{J}$ Microbial Res, 2(1): 28-37.

[19] Abdel Wahab, M.B. and Shigidi M.T.A. (2013): Susceptibility of Corynebacterium pseudotuberculosis isolated from sheep and goats with caseous lymphadenitis to Some antimicrobial agents. The Sudan J Vet Res, 28: 10-12. 
[20] Garcia-Bravo, M.; Aguado, J.M.; Morales, J.M. and Noriega, A.R. (1996): Influence of external factors in resistance of Corynebacterium urealyticum to antimicrobial agents. Antimicrob Agents Chemother, 40 (2): 497-499.

[21] Arthur, M.; Nolinas, C.; Mabilat, C. and Courvalin, P. (1990): Detection of erythromycin resistance by the polymerase chain reaction using primers in conserved region of erm rRNA methylase genes. Antimicrob Agents Chemother, 34 (10): 2024-2026.

[22] Roberts, M.C.; Sutcliffe, J.; Courvalin, P.; Jensen, L.B.; Rood, J. and Seppala, H. (1999): Nomenclature for macrolide and macrolide-lincosamide-streptogramin $B$ resitance determinants. Antimicrob Agents Chemother, 43 (12): 2823-2830.

[23] Pavan, M.E.; Robles, C.; Cairó, F.M.; Marcellino, R. and Pettinari, M.J.(2012): Identification of Corynebacterium pseudotuberculosis from sheep by PCRrestriction analysis using the RNA polymerase b-subunit gene $(r p o \mathrm{~B})$. Res Vet Sci, 92 (2): 202-206.

[24] Khamis, A.; Raoult, D. and La Scola B. (2005): Comparison between rpoB and 16S rRNA gene sequencing for molecular identification of 168 clinical isolates of Corynebacterium. J Clin Microbiol, 43 (4): 1934-1936.

\section{الملخص العربي}

\section{التوصيف الجزيئي و الحساسية للمضادات الحيوية لعترات وتدية السل الكاذب المعزولة من الاغنام والماعز التي تعاني من إلتهاب العقد الليمفاوية التجبني التئي}

عبدالعظيم حمح الجمال

قسم البكتريـا و المناعة و الفطـرياتـــلية الطب البيطـــىــ جامعة قناة السويس

إلتهاب العقد الليمفاوية التجبني (السل الكاذب) هو مرض واسع الانتشار في جميع أنحاء العالم ويصيب الأغنام و الماعزويسببه

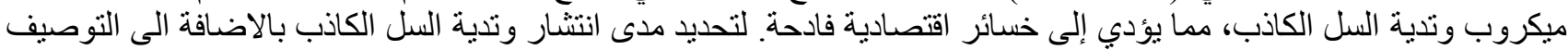

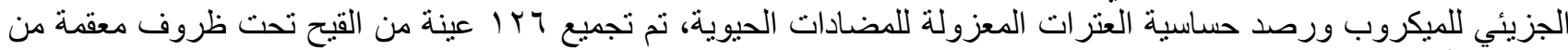

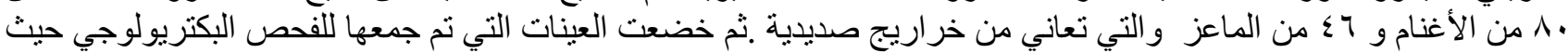

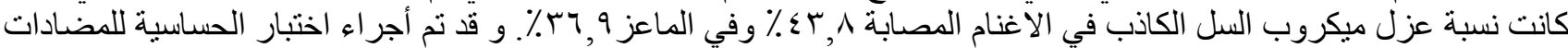

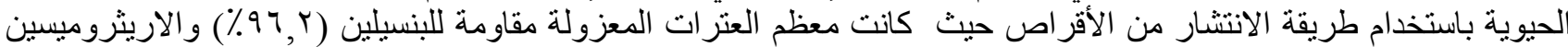

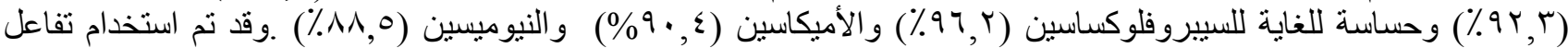
البلمرة المتسلسل للكثف عن تو اجد جينات (16S rRNA) و(rpoB) في • من من العترات المعزولة لتاكيد تشخيصها حيث كانت

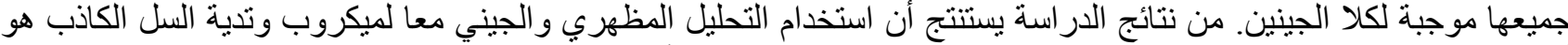
أداة قيمة لتوصيف العترات المعزولة. كما يعتبر تفاعل البلمرة المتسلسل أداة تشخيصية قيمة وسريعة ومحددة تستخدم للتوصيف الجيني للميكروب. 